\title{
PEMBELAJARAN BERBASIS ICT RELIGI MODEL ANIMASI UNTUK MENINGKATKAN KARAKTER DAN PRESTASI BELAJAR LISTRIK DINAMIS PADA PESERTA DIDIK SMA NEGERI 8 SURAKARTA
}

\author{
Amin Muslih $^{1}$, Widha Sunarno ${ }^{2}$ dan Nonoh Siti Aminah ${ }^{3}$ \\ ${ }^{1}$ SMA Negeri 8 Surakarta \\ Surakarata, 57127, Indonesia \\ muslihamin@gmail.com \\ ${ }^{2}$ Program Studi Pendidikan Sains. Program Pasca Sarjana UNS \\ Surakarata, 57126, Indonesia \\ widhasunarno@gmail.com \\ ${ }^{3}$ Program Studi Pendidikan Sains. Program Pasca Sarjana UNS \\ Surakarata, 57126, Indonesia \\ nonoh_nst@yahoo.com
}

\begin{abstract}
Abstrak
Tujuan penelitian tindakan ini untuk memperbaiki proses pembelajaran fisika dan untuk meningkatkan karakter: religius, jujur, disiplin, cinta tanah air dan peduli sosial serta prestasi belajar fisika kompetensi listrik dinamis. Penelitian dilaksanakan di SMA Negeri 8 Surakarta tahun 2012/2013 semester 2 dengan subjek penelitian kelas X 7. Pembelajaran berbasis ICT religi model animasi dengan metode demonstrasi dan penugasan. Hasil penelitian menunjukkan perubahan lebih baik pada aktivitas belajar dalam hal: kedisiplinan, belajar berpusat pada siswa, ketertiban dalam pembelajaran, tanggung jawab, kejujuran, kerjasama yang baik. Perubahan aktivitas belajar mengefektifkan difusi inkulkasi dan keterampilan asertif dari bahan ajar berbasis ICT religi, sehingga karakter menjadi lebih baik. Perubahan karakter meningkatkan kemampuan berpikir yang dimanifestasikan perilaku lebih santun, dan prestasi belajar lebih baik secara induvidual dan klasikal. Data prestasi belajar predikat baik, ketuntasan belajar, dan koefisien varian, berturut-turut pada prasiklus: $15 \%, 59 \%$, dan 15\%, meningkat pada siklus 1 menjadi: $33 \%, 78 \%$, dan 14\%, meningkat lagi pada siklus 2 menjadi 85\%, 96\%, dan 9\%.
\end{abstract}

Kata kunci: ICT Religi; Animasi; Karakter: Prestasi Belajar.

\section{Pendahuluan}

Penerapan pendidikan karakter di SMA Negeri 8 Surakarta telah berjalan lebih dari 3 tahun, namun antara usaha yang telah dilakukan dan hasil yang harapan adanya perilaku peserta didik yang menjiwai karakter luhur bangsa masih ada kesenjangan. Kesenjangan itu antara lain: setiap hari masih ada peserta didik tidak disiplin datang ke sekolah/masuk kelas pada saat pergantian jam pelajaran. Peserta didik pada saat pembelajaran kurang memperhatikan pelajaran yang disampaikan oleh guru, secara sembunyi-sembunyi bermain smartphone. Apabila ada tugas jarang dikerjakan dan ketika diberi pertanyaan tidak dapat menjawab bahkan tidak mau bertanya meskipun menemui kesulitan. Pada saat pelaksanaan pembelajaran peserta didik juga sering mengantuk, tidur-tiduran di meja atau berbicara selain materi pelajaran dengan teman dekatnya. Praktik pengamalan ibadah ritual seperti sholat dhuhur hanya sedikit yang melaksanakan. Prestasi belajar fisika kompetensi listrik dinamis yang masih rendah, hal ini dikuatkan hasil analisis 
ujian nasional yang dikeluarkan oleh BNSP dari tahun pelajaran 2009/2010 sampai tahun 2011/2012 untuk peserta didik di SMA Negeri 8 Surakarta didapatkan prosentase daya serap materi hanya sebesar $57.69 \%$. Semua ini adalah salah satu dampak penggunaan gadget yang tidak tepat. Usaha mengatasi kesenjangan penerapan pendidikan karakter di SMA Negeri 8 Surakarta akan dilakukan penelitian tindakan kelas dengan menggunakan pembelajaran berbasis ICT religi model animasi, pada mata pelajaran fisika.

Mata pelajaran fisika adalah bagian dari sains yang cukup potensial membentuk karakter. Sains diyakini berperan penting dalam pengembangan karakter warga masyarakat dan negara, karena kemajuan produk sains yang amat pesat, keampuhan proses sains yang dapat ditransfer pada berbagai bidang lain, dan kekentalan muatan nilai, sikap, dan moral di dalam sains menurut Rotherford \& Ahlgren (dalam Zuchdi, 2013 : 34).

Dimasukkan nilai-nilai agama atau religi pada ICT pada proses pembelajaran fisika, diharapkan menjadi filter terhadap arus informasi global lebih efektif bekerja. Peserta didik tetap dapat terus mengembangkan diri dengan kemajuan ICT. Mengingat hidup di era informasi abad 21 ini merupakan kenyataan bahwa ICT telah menjadi bagian yang tidak terpisahkan dari kehidupan era global. Untuk mendorong kesiapan SDM di era global melalui pendidikan di sekolah dengan pengintegrasian ICT dan religi ke dalam proses pembelajaran.

Tujuan penelitian ini adalah: (1) pembelajaran berbasis ICT Religi model animasi untuk memperbaiki proses pembelajaran fisika di SMA Negeri 8 Surakarta; (2) pembelajaran berbasis ICT Religi model animasi untuk meningkatan karakter religius, jujur, disiplin, cinta tanah air dan peduli sosial pada peserta didik kelas X 7 di SMA Negeri 8 Surakarta; (3) pembelajaran berbasis ICT Religi model animasi untuk meningkatkan prestasi belajar fisika kompetensi: Menerapkan konsep kelistrikan dalam berbagai penyelesaian masalah dan berbagai produk teknologi (listrik dinamis) pada peserta didik kelas X 7 di SMA Negeri 8 Surakarta.

Beberapa landasan teori yang digunakan untuk mencapai tujuan penelitian. Teori itu antara lain: pengertian karakter, prestasi belajar, teori-teori belajar dan hubungan religi dan sains.

Karakter menurut (Suyanto: 2011) adalah cara berpikir dan berperilaku yang menjadi ciri khas tiap individu untuk hidup dan bekerjasama, baik dalam lingkup keluarga, masyarakat, bangsa dan negara. Individu yang berkarakter baik adalah individu yang bisa membuat keputusan dan siap mempertanggungjawabkan tiap akibat dari keputusan yang ia buat. Sedangkan menurut Zuchdi (2013: 11) karakter atau watak adalah seperangkat sifat-sifat yang selalu dikagumi sebagai tanda-tanda kebaikan, kebajikan, dan kematangan moral.

Karakter merupakan ciri khas seseorang atau sekelompok orang yang menampilkan seperangkat sifat yang selalu dikagumi sebagai tanda-tanda kebaikan, kebijakan, dan kematangan moral, yang bersumber dari perpaduan pengembangan olah hati, olah pikir, olah raga, serta olah rasa dan karsa yang mengandung value, kemampuan, kapasitas moral, dan ketegaran dalam menghadapi kesulitan dan tantangan.

Prestasi belajar menurut Abin Syamsudin (2003: 7), menyatakan bahwa: "Prestasi belajar merupakan indikator dari perubahan dan perkembangan perilaku dalam term-term pengetahuan (penalaran) sikap (penghayatan) dan keterampilan (pengalaman). Perubahan dan perkembangan ini mempunyai arah yang positif dan negatif dan kualifiksinya pun akan terbagi-bagi, seperti tinggi, sedang, rendah atau berhasil, tidak berhasil, dan 
lulus tidak lulus. Kriteria tersebut akan tergantung pada diri peserta didik itu sendiri”.

Prestasai belajar menurut Hamalik (2003: 68), adalah sesuatu yang dibutuhkan seseorang untuk mengetahui kemampuan setelah melakukan kegiatan yang bersifat belajar, karena prestasi adalah hasil belajar yang mengandung unsur hasil penilaian, hasil usaha kerja, dan ukuran kecakapan yang dicapai suatu saat. Selanjutnya Muhibbin Syah (2008: 141), menyatakan bahwa "Prestasi belajar digunakan untuk menentukan taraf keberhasilan sebuah proses belajar mengajar atau untuk menentukan taraf keberhasilan sebuah program pengajaran".

Hakikat prestasi belajar adalah perubahan perilaku dalam individu yang dimanifestasikan ke dalam pola tingkah laku, keterampilan dan pengetahuan sebagai hasil belajar yang disadari dan dapat diukur berdasarkan kriteria yang telah ditetapkan selama mengikuti kegiatan proses pembelajaran. Dapat pula dikatakan bahwa prestasi belajar yang dicapai perserta didik merupakan aktualisasi dari potensi perserta didik yang diperoleh melalui kegiatan belajar dengan materi dalam kriteria tertentu, sesuai dengan kurikulum yang berlaku.

Usaha peningkatan karakter dan prestasi belajar dalam penelitian ini akan digunakan pembelajaran berbasis ICT religi model animasi. Perkembangan ICT telah memberikan kontribusi terhadap terjadinya revolusi dalam berbagai bidang, termasuk bidang pendidikan Eric Ashby dalam (Rusman: 2010).

Teori belajar yang sejalan dengan pembelajaran berbasis ICT religi model animasi antara lain: teori belajar behaviorisme dan teori belajar konstruktivisme. Teori belajar behaviorisme berpandangan bahwa proses pembelajaran terjadi sebagai hasil pengajaran yang disampaikan guru melalui atau dengan bantuan media (alat). Tokoh yang terkenal dalam teori ini antara lain: Burrhus Frederic Skinner
(1904-1990), Robert Gagne ( 1916-2002) dan Albert Bandura (1925- sampai sekarang ).

Tokoh yang berperan pada teori konstruktivisme ini antara lain Jean Piaget dan Vygotsky. Teori Piaget (1952) menurut Anita Lei (2008: 4) ada empat pokok pemikiran yang harus diperhatikan oleh pendidik dalam menyusun dan melaksanakan pembelajaran: (1) pengetahuan ditemukan, dibentuk dan dikembangkan oleh siswa; (2) siswa membangun pengetahuan secara aktif; (3) pengajar perlu berusaha mengembangkan kompetensi dan kemampuan siswa; (4) pendidikan adalah interaksi pribadi di antara para siswa dan interaksi anatra guru dan siswa.

Menurut Shihab (1996: 41) hubungan ilmu pengetahuan dan teknologi (sains) dengan nilai-nilai agama/religi (Al Quran) adalah di dalam Al Quran yang terdiri 6.666 ayat, belum ada satu ayatpun yang menghalangi kemajuan ilmu pengetahuan atau sebaliknya, tidak ada satu ayatpun dari $\mathrm{Al}$ Quran yang bertentangan dengan hasil penemuan ilmiah yang telah mapan. Hubungan sains dan religi yang terpenting adalah meletakkan antara sains dan religi pada sisi social psychology, bukan pada sisi history of scientific progress. Jika setiap ayat mengandung suatu teori ilmiah, maka hasilnya adalah keuntungan yang diperoleh dari mengamalkan teori-teori tersebut sewaktu hidup di dunia dan di akherat kelak.

Pembelajaran berbasis ICT religi model animasi dalam penelitian ini adalah program pembelajaran yang menggunakan software komputer yang berisikan program-program komputer tentang materi pembelajaran fisika listrik dinamis yang meliputi: judul, tujuan, materi pembelajaran, dan evaluasi pembelajaran yang telah diberi muatan religi sebagai filter efek negatif dari penggunaan ICT.

\section{Metode Penelitian}


Penelitian Tindakan Kelas (PTK) ini dilaksanakan di SMA Negeri 8 Surakarta pada tahun pelajaran 2012/2013, dimulai pada bulan Desember tahun 2012 sampai dengan bulan Juni 2013. Ada enam uraian urutan kegiatan sebagai berikut: (1) penyusunan proposal dan instrumen penelitian dilaksnakan pada bulan Desember 2012 sampai dengan Januari 2013; (2) validasi instrumen penelitian dengan validasi ahli dari dosen UNS pada bulan Februari dan Maret 2013; (3) uji coba instrumen di SMA Batik 2 Surakarta, pada bulan April 2013; (4) pelaksanaan penelitian akhir bulan April sampai dengan bulan Mei 2013; (5) analisis data dan penyusunan laporan penelitian pada bulan Mei dan Juni 2013; (6) penyusunan hasil penelitian dalam jurnal ilmiah pada bulan Juli 2013.

Penelitian ini berfungsi untuk memperbaiki kualitas pembelajaran (Teaching Learning Quality). Jika kualitas pembelajaran meningkat maka prestasi belajar peserta didik meningkat. PTK ini fokuskan untuk mencari pemecahan masalah yang dialami oleh guru dan peserta didik di SMA Negeri 8 Surakarta.

PTK menurut (Suharjono, Supardi, 2011: 85), terdiri dari empat kegiatan yang berulang-ulang disebut dengan siklus, satu siklus terdiri dari: (1) perencanaan tindakan; (2) pelaksanan tindakan; (3) pengamatan dan pengumpulan data; (4) refleksi. Siklus 2 merupakan perbaikan tindakan dari siklus 1, akibat masih dijumpai adanya kelemahan atau kekurangan pada tindakan siklus I, maka perlu adanya perencanaan yang lebih baik dan lengkap dari metode yang telah dilakukan.

Subjek penelitian dalam tindakan kelas ini mengambil peserta didik kelas X-7 semester 2 tahun pelajaran 2012/2013, yang berjumlah 27 orang peserta didik, semuanya beragama Islam. Gambaran kondisi kebiasan peserta didik kelas X-7 selama peneliti mengajar mata pelajaran fisika, karakter yang ditampilkan masih rendah. Praktik pengamalan ibadah ritual seperti sholat dhuhur hanya sedikit yang melaksanakan. Kelebihan kelas X-7 adalah rata-rata peserta didik mempunyai gadget, mampu mengoprasionalkan, dan tidak gagap teknologi. Kelebihan yang dimiliki peserta didik X-7 tersebut akan digunakan untuk menutupi kekurangan yang ada yaitu rendahnya karakter dan prestasi belajar fisika.

Sumber data untuk analisis dan pembahasan dalam PTK diambil dari sumber data primer yaitu sumber data didapat dari subjek penelitian, yaitu observasi langsung aktivitas belajar dan karakter selama pembelajaran serta prestasi belajar dari hasil ulangan harian sebanyak tiga kali pada peserta didik kelas X 7. Data primer juga diperoleh dari hasil pengamatan yang dilakukan oleh teman sejawat sebagai observer dalam penelitian tindakan ini terutama pada proses pembelajaran.

Instrument prestasi belajar sebelum dipraktikkan/digunakan terlebih dahulu dilakukan validasi dan uji coba dalam hal: (1) uji validitas isi menunjukkan ketepatan antara obyek yang diukur dengan alat ukur. Agar tes mempunyai validitas isi, menurut Budiyono (2009: 58); (2) reliabilitas menunjukkan pada keajegan hasil pengukuran (Budiyono 2009: 69); (3) daya beda yang baik jika kelompok peserta didik yang pandai menjawab benar lebih banyak dari kelompok yang kurang pandai (Aminah 2012: 9); (4) tingkat kesukaran butir soal dan penafsiran (interpretasi) terhadap angka indeks kesukaran item, Robert L.Thorndike dan Elizabeth Hagen (dalam Anas Sudijono, 2007: 372).

Instrument untuk pengumpulan data pada penelitian ini ada beberapa jenis yaitu: (1) teknik tes, alatnya dapat berbentuk butir soal tes; (2) teknik non tes, alatnya dapat berbentuk lembar observasi (aktivitas proses pembelajaran dan karakter); (3) lembar tugas sebagi 
panduan bagi peserta didik belajar di luar kelas .

Penilaian karakter dilakukan dengan melakukan observasi perilaku peserta didik dengan menggunakan skala penilaian (rating scale). Penggunaan skala penilaian memungkinkan penilai memberi skor/nilai terhadap karakter tertentu secara lebih cermat. Praktik penilaian karakter digunakan instrumen observasi yang diisi oleh subjek penelitian sebagai evaluasai diri dan format obsevasi yang diisi oleh peneliti, dari dua sumber penilaian kemudian digabung diambil nilai rata-ratanya.

Untuk penilaian prestasi belajar disediakan dua paket soal. Satu paket soal terdiri dari 21 butir soal pilihan ganda, yang berisikan soal-soal KD. 51: Memformulasikan besaran-besaran listrik rangkain listrik sederhana (satu loop), dan paket ke dua terdiri 22 butir soal berisikan soal-soal KD. 5.2: Mengidentifikasi penerapan listrik AC dan DC dalam kehidupan sehari-hari. Hasil ulangan harian merupakan data untuk prestasi belajar fisika, data yang ada kemudian dianalisis.

Analisis data pada penelitian tindakan ini menggunakan statistik dengan menggunakan program pengolah angka excel dari software Microsoft Office, data yang telah diolah dinyatakan dalam tabel dan grafik. Pengelompokan data angka dari observasi non tes (aktivitas proses pembelajaran dan karakter) dan data tes (prestasi belajar) agar lebih mudah dipahami secara kualitatif dan kuantitatif, maka dikelompokkan dengan skal sebagai berikut: (1) $90-100=$ baik sekali; (2) 80-89 = baik; (3) $70-79$ = sedang; $(4)<70 \quad=$ kurang

Analisis data pada penelitian tindakan kelas, data kualitatif dikelompokkan berdasarkan karaktristik yang sama, kemudian disajikan dalam bentuk tabel dan grafik, data kuantitatif diolah menggunakan analisis diskriptif komparatif yaitu membandingkan hasil pengamatan aktivitas belajar dan hasil nilai tes ulangan harian kondisi awal (prasiklus), nilai ulangan harian setelah siklus 1 dan nilai ulangan harian setelah siklus 2. Kemudian di refleksi untuk perbaikan pada siklus 1 dan siklus 2.

Indikator kinerja pada tindakan kelas ini menggunakan indikator kinerja sesuai dengan rumusan masalah yaitu, pertama pengamatan pada aktivitas peserta didik dalam mengikuti proses pembelajaran, kehadiran dalam mengikuti pelajaran, kelancaran/ketepatan waktu yang direncanakan dengan kenyataan di lapangan, dan yang terakhir adalah hasil belajar/prestasi belajar peserta didik. Penelitian ini dikatakan telah berhasil meningkatkan kualitas pembelajaran, jika penilai karakter dan prestasi belajar masing-masing subjek penelitian minimal 70 dengan ketuntasan belajar $85 \%$ secara kalsikal.

\section{Hasil Penelitian dan Pembahasan}

Tindakan dalam penelitian ini terdiri dua siklus. Tindakan pertama mulai dilaksanakan pada hari Rabu, 24 April 2013 sampai dengan hari Senin, 20 Mei 2013, dalam 8 kali pertemuan dengan total alokasi waktu 12 x 45' di SMA Negeri 8 Surakarta. Sebelumnya telah diambil data dari subjek penelitian yang sama, dalam empat kali pertemuan, berupa data observasi karakter, aktivitas proses pembelajaran dan prestasi belajar, selanjutnya data awal ini disebut data prasiklus. Penelitian tindakan kelas ini mempunyai tiga jenis data dari hasil pengamatan dan pengukuran/penilaian yaitu: data prasiklus, data siklus 1 , dan data siklus 2. Seperti terlihat pada Tabel 1 adalah rekapitulasi dari hasil observasi aktivitas proses pembelajaran selama penelitian berlangsung.

Tabel 1. Aktivitas Proses Pembelajaran 


\begin{tabular}{|c|c|c|c|}
\hline \multirow{2}{*}{$\begin{array}{l}\text { Aktivitas } \\
\text { Pembelajaran }\end{array}$} & \multicolumn{3}{|c|}{$(\%)$ dalam $4 \times$ pertemuan } \\
\hline & Prasiklus & Siklus 1 & Siklus 2 \\
\hline Tidak Disiplin & 26 & 15 & 4 \\
\hline $\begin{array}{l}\text { Pembelajaran } \\
\text { berpusat pada Guru }\end{array}$ & 67 & 41 & 19 \\
\hline $\begin{array}{l}\text { Pembelajaran } \\
\text { berpusat pada Siswa }\end{array}$ & 33 & 59 & 81 \\
\hline $\begin{array}{l}\text { Kurang } \\
\text { Memperhatikan } \\
\text { Pembelajaran }\end{array}$ & 48 & 26 & 15 \\
\hline $\begin{array}{l}\text { Tidak mengerjakan } \\
\text { tugas }\end{array}$ & 56 & 26 & 19 \\
\hline Menyontek & 19 & 7 & 4 \\
\hline
\end{tabular}

Berdasarkan data hasil penelitian mulai dari prasiklus, siklus 1 , dan siklus 2 seperti pada Tabel 1, membuktikan telah terjadi perubahan aktivitas proses pembelajaran yang lebik baik. Hal itu ditunjukkan dengan meningkatnya pembelajaran yang berpusat pada siswa dan kerja sama yang baik. Sebaliknya aktivitas proses pembelajaran yang tidak baik mengalami penurunan seperti perilaku tidak disiplin, tidak memperhatikan saat pembelajaran, tidak mengerjakan tugas yang telah diberikan oleh guru, menyontek saat ulangan harian, dan pembelajaran yang berpusat pada guru prosentasenya mengalami penurunan.

Perubahan aktivitas pembelajaran pada Tabel 1 terjadi karena pembelajaran telah menggunakan bahan ajar listrik dinamis berbasis ICT religi model animasi. Bahan ajar berbasis ICT religi model animasi adalah bahan ajar yang memuat materi pembelajaran yang lengkap mulai dari judul, tujuan, materi pembelajaran, dan evaluasi pembelajaran, yang disajikan dalam model animasi dan materi terintegrasi dengan materi religi untuk pembentukan karakter. Sifat bahan ajar listrik dinamis antara lain: menarik untuk dipelajari, fleksibel dan kecil ukuran filenya. File dapat dijadikan dalam bentuk format dengan extensi .ppt (ukuran file: 4,52 MB) atau .swf (ukuran file: 7,25 MB) yang mudah disimpan dalam bentuk keping CD/DVD, atau flash disk, dan mudah ditransfer lewat email atau jejaring sosial. Dengan sifat bahan ajar tersebut peserta didik dengan leluasa dapat membuka bahan ajar tersebut kapan saja baik di dalam kelas atau di luar kelas/di rumah dengan bantuan unit gadget (komputer) untuk mengaksesnya. Bahan ajar listrik dinamis berbasis ICT religi juga dapat diunduh secara online pada alamat: http://muslihamin.blogspot.com/.

Sifat bahan ajar yang fleksibel dan meyenangkan bagi peserta didik berdampak pada perubahan aktivitas proses pembelajaran yang lebih baik. Perubahan proses pembelajaran yang baik dapat mengubah sikap dan perilaku peserta didik yang lebih baik, selanjutnya dapat meningkatkan karakter peserta didik, seperti data pada Tabel 2.

Proses pembelajaran yang menarik, fleksibel, dan menyenangkan mengakibatkan terjadinya proses difusi inkulkasi (penanaman nilai tanpa indoktrinasi), keteladanan dari guru dan keterampilan asertif (keterampilan mengemukakan pendapat secara terbuka, dengan cara-cara yang tidak melukai perasaan orang lain) yang berasal dari bahan ajar berbasis ICT religi model animasi belangsung lebih efektif. Bukti terjadi peningkatan karakter religius, jujur, disiplin, cinta tanah air dan peduli sosial seperti data pada Tabel 2.

Tabel 2. Peningkatan Karakter 


\begin{tabular}{lccc}
\hline \multicolumn{1}{c}{ Jenis } & \multicolumn{3}{c}{$(\%)$ Ketuntasan Karakter } \\
\cline { 2 - 4 } Karakter & Prasiklus & Siklus 1 & Siklus 2 \\
\hline Religius & 44 & 96 & 100 \\
Jujur & 52 & 85 & 89 \\
$\begin{array}{l}\text { Disiplin } \\
\text { Cinta }\end{array}$ & 78 & 81 & 96 \\
$\begin{array}{l}\text { Tanah Air } \\
\text { Peduli }\end{array}$ & 74 & 74 & 96 \\
Sosial & 81 & 89 & 96 \\
\hline
\end{tabular}

Tabel 2, dapat dijelaskan sebagai berikut: Karakter religius mengalami peningkatan ketuntasan paling tinggi yaitu $66 \%$ dari prasiklus yang hanya $44 \%$ dan mencapai $100 \%$ pada akhir siklus 2. Karakter jujur meningkat $37 \%$ dari $52 \%$ pada prasiklus menjadi $89 \%$ pada akhir siklus 2. Karakter cinta tanah air meningkat $22 \%$ dari $74 \%$ pada prasiklus menjadi $96 \%$. Karakter disiplin juga mengalami peningkatan $18 \%$ dari $78 \%$ pada prasiklus menjadi $96 \%$ pada akhir siklus 2. Karakter peduli sosial mengalami peningkatan paling kecil hanya $15 \%$ dari $81 \%$ pada prasiklus menjadi $96 \%$ pada akhir siklus 2 . Rendahnya peningkatan karakter peduli sosial salah satu penyebabnya adalah adanya perbedaan kelompok besar (4-5 peserta didik) pada siklus 1 menjadi kelompok kecil (2-3 peserta didik) pada siklus 2. Praktik pembelajaran pada siklus 1 dalam kelompok hanya didominasi oleh 1-2 peserta didik saja, akan tetapi pada siklus 2 semua anggota kelompok terlibat aktif dalam pembelajaran. Keaktifan semua peserta didik dalam proses pembelajaran pada siklus 2 dapat memperbaiki prestasi belajar peserta didik pada siklus 2 , seperti data pada Tabel 3 .

Peningkatan karakter religius, jujur, disiplin, cinta tanah air dan peduli sosial pada peserta didik menimbulkan motivasi belajar yang lebih kuat. Belajar dipandang sebagai ibadah kepada Tuhan Yang Maha Esa dan amanah dari orangtua peserta didik, karena belajar sebagai ibadah dan amanah maka peserta didik lebih tertib dan lebih tekun belaja. Akhirnya dapat meningkatkan kemampuan berpikir pada peserta didik yang lebih baik, dimanifestasikan ke dalam pola prilaku, keterampilan dan pengetahuan (prestasi belajar) secara induvidual maupun klasikal. Data peningkatan prestasi belajar ada pada Tabel 3.

Tabel 3. Peningkatan Prestasi Belajar

\begin{tabular}{lccc}
\hline $\begin{array}{l}\text { Katagori Prestasi } \\
\text { Belajar }\end{array}$ & Prasiklus & $\begin{array}{c}\text { Siklus } \\
\mathbf{1}\end{array}$ & $\begin{array}{c}\text { Siklus } \\
\mathbf{2}\end{array}$ \\
\hline $\begin{array}{l}(90-100)=\text { Baik } \\
\text { Sekali } \\
(80-89)=\text { Baik }\end{array}$ & $\mathbf{0 \%}$ & $\mathbf{7 \%}$ & $\mathbf{3 7 \%}$ \\
$(70-79)=$ Sedang & $\mathbf{4 4 \%}$ & $\mathbf{2 6 \%}$ & $\mathbf{4 8 \%}$ \\
$<70=$ Kurang & $\mathbf{4 1 \%}$ & $\mathbf{2 2 \%}$ & $\mathbf{4 \%}$ \\
\hline Nilai minimem & 47 & 52 & 64 \\
\hline Nilai maksimem & 85 & 90 & 95 \\
\hline Nilai rata-rata & 69 & 74 & 87 \\
\hline Standar Deviasi & 11 & 11 & 8 \\
\hline Jumlah yang tuntas & 16 & 21 & 26 \\
\hline$\%$ ketuntasan & $59 \%$ & $78 \%$ & $96 \%$ \\
\hline Koefisien varian & $15 \%$ & $14 \%$ & $9 \%$ \\
\hline
\end{tabular}

Nilai rata-rata prestasi belajar yang semula hanya 69 pada prasiklus, meningkat menjadai 74 pada siklus 1 dan 87 pada siklus 2. Prosentasae jumlah peserta didik yang tuntas belajar semula $59 \%$ pada prasiklus, meningkat menjadi $78 \%$ pada siklus 1 dan $96 \%$ pada siklus 2. Koefisien varian yang menunjukkan adanya tingkat perbedaan penguasaan materi pada peserta didik mengalami penurunan dari $15 \%$ pada prasiklus turun menjadi $14 \%$ pada siklus 1 , dan $9 \%$ pada siklus 2.

Ada satu hal yang menarik untuk dibahas hasil penelitian yang yaitu terjadinya keserasian antara karakter religius dan prestasi belajar pada subjek penelitian di kelas X-7 SMA Negeri 8 Surakarta, semester genap tahun pelajaran 2012/2013. Subjek penelitian yang berkarakter religius baik (tinggi) juga menunjukkan prestasi belajar yang baik (tinggi) dan sebaliknya jika subjek 
penelitian berkarakter kurang (rendah) maka prestasi belajar juga kurang (rendah). Seperti terlihat pada diagram pada gambar 1 .

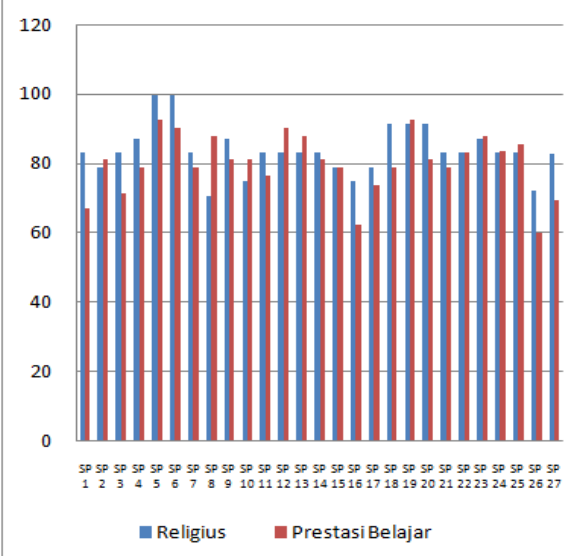

Gambar 1. Diagram Batang Karakter Religius dan Prestasi Belajar

Penjelasan gambar 1. Diagram batang menunjukkan keserasian antara karakter religius dan prestasi belajar. Setiap Subjek Penelitian (SPx) yang memiliki karakter religius tinggi (warna biru) juga menunjukkan prestasi belajar yang baik (warna merah). Ada $10 \mathrm{SP}$ (37\%) yang tingginya seimbang/hampir sama yaitu: $\mathrm{SP}_{2}, \mathrm{SP}_{7}, \mathrm{SP}_{10}, \mathrm{SP}_{11}, \mathrm{SP}_{14}$, $\mathrm{SP}_{15}, \mathrm{SP}_{19}, \mathrm{SP}_{22}, \mathrm{SP}_{23}$ dan $\mathrm{SP}_{24}$. Secara umum data nilai karakter religius dan prestasi belajar pada siklus 2 didapatkan rata-rata sebesar( ) 82, dengan standar deviasai (std) 8, sehingga didapatkan nilai Koefisien Varian $(\mathrm{KV})=\frac{s t d}{\bar{x}} \times 100$ $\%$, maka didapatkan tingkat keseragaman (homogen) sebesar 9\%.

Perubahan karakter religius menjadi lebih baik mempengarui perubahan karakter yang lain dan dapat meningkatkan prestasi belajar. Kondisi ini sejalan dengan penelitian-penelitian lain terdahulu, seperti yang dikemukanan oleh Abin Syamsudin (2003:7), menyatakan bahwa: Prestasi belajar merupakan indikator dari perubahan dan perkembangan perilaku dalam term-term pengetahuan (penalaran) sikap (penghayatan) dan keterampilan (pengalaman). Perubahan dan perkembangan ini mempunyai arah yang positif dan negatif. Peningkatan karakter dan prestasi belajar ini juga sejalan dengan hasil penelitian yang telah dilakukan oleh Maimun et. al (2011) Penggunaan ICT dalam pembelajaran religi Agama Islam dapat membantu pengembangan berpikir positif, meningkatkan kemampuan berinovasi dan memicu untuk perbaikan diri. Makalah lain yang senada adalah: makalah dari Bill Cobern (2007). Pembelajaran Fisika Berbasis Nilai Agama pada Perguruan Tinggi Agama Islam, Chairul (2010). Salah satu hasil yang diungkapkan adalah: kemampuan peserta didik dalam pengintegrasikan nilai Agama Islam dapat diprediksi kemampuan akademiknya.

Pembahasan hasil penelitian pembelajaran berbasis ICT religi model animasi yang telah diuraikan tersebut, jika diambil intisarinya akan didapatkan ciri khas pembelajaran fisika materi listrik dinamis berbasis ICT religi model animasi. Ciri khas itu antara lain: (1) pembelajaran menggunakan bahan ajar yang menggunakan software komputer berisikan program-program komputer dengan materi pembelajaran yang meliputi: judul, tujuan, materi pembelajaran, dan evaluasi pembelajaran, disajikan dalam model animasi dan materi terintegrasi dengan pembentukan karakter; (2) materi pelajaran lebih menarik untuk dipelajari, fleksibel, dan file bahan ajar ukuran kecil, mudah disimpan dalam bentuk keping CD/DVD, atau flash disk, serta mudahditransfer lewat email atau jejaring sosial sehingga mudah disebarkan ke pengguna yang lain, cocok untuk belajar kelompok kecil 
(2-3 orang) tetapi dengan jangkauan penyebaran yang luas; (3) mendukung terjadinya proses belajar aktif, konstruktif, kolaboratif, dan reflektif; (4) meningkatkan karakter lebih mulia dan prestasi belajar yang lebih baik, pada peserta didik.

\section{Kesimpulan dan Rekomendasi}

Pelaksanaan penelitian tindakan kelas dengan menerapkan pembelajaran berbasis ICT religi model animasi pada peserta didik SMA Negeri 8 Surakarta kelas X 7 semester genap tahun pelajaran 2012/2013 untuk materi listrik dinamis dapat diambil simpulan akhir sebagai berikut: (1) pembelajaran berbasis ICT religi model animasi dapat memperbaiki proses pembelajaran mata pelajaran fisika yang lebih baik; (2) pembelajaran berbasis ICT Religi model animasi dapat mengefektifkan inkulkasi (penanaman nilai tanpa indoktrinasi) dan ketrampilan asertif (ketrampilan mengemukakan pendapat secara terbuka, dengan cara-cara yang tidak melukai perasaan orang lain) dan dapat meningkatkan karakter: religius, jujur, disiplin, cinta tanah air serta peduli sosial pada subjek penelitian sehingga dapat mengubah perilaku yang lebih baik dan santun; (3) pembelajaran listrik dinamis berbasis ICT Religi model animasi dapat meningkatkan kemampuan berpikir peserta didik yang dimanifestasikan kedalam pola perilaku, keterampilan dan pengetahuan (prestasi belajar) secara individual dan peningkatan ketuntasan belajar dalam tingkat keseragaman penguasaan kompetensi listrik dinamis secara klasikal.

Simpulan akhir dari penelitian pembelajaran fisika materi listrik dinamis berbasis ICT religi model animasi, mempunyai implikasi praktis yang dapat direkomendasikan untuk sesama guru mata pelajaran fisika, peserta didik dan satuan pendidikan.

Rekomendasi untuk sesama guru mata pelajaran fisika SMA, penelitian ini memberi manfaat antara lain: (1) guruguru fisika dapat langsung mengunduh bahan ajar pada alamat: http://muslihamin.blogspot.com/, dan menanfaatkan bahan ajar listrik dinamis berbasis ICT religi model animasi dalam proses pembelajaran; (2) bahan ajar listrik dinamis ini sebagai bahan masukan dan alternatif pembelajaran untuk peningkatan karakter dan prestasi belajar peserta didik; (3) bahan ajar ini bersifat terbuka sehingga dapat dikembangkan oleh siapa saja sesuai dengan kebutuhan dengan cara diamati, ditiru dan dimodifikasi.

Rekomendasi untuk peserta didik, penelitian ini bermanfaat untuk: (1) menarik minat belajar dengan menumbuhkan aktivitas belajar yang kreatif dan bermakna; (2) berperilaku dengan karakter yang lebih mulia; (3) melatih kemampuan berpikir untuk meningkatkan prestasi belajar fisika kompetensi listrik dinamis.

Rekomendasi untuk satuan pendidikan, penelitian ini bermanfaat untuk: (1) meningkatkan kualitas lulusan dari satuan pendidikan yang memiliki sumber daya manusia (SDM) yang unggul: berbudi pekerti luhur, berprestasi dan kompetitif; (2) untuk mewujudkan SDM yang unggul perlu kerukunan, kekompakan dan kerjasama yang baik antara kepala satuan pendidikan, dewan guru dan tenaga kependidikan dalam hal pengadaan sarana ICT berbasis religi di satuan pendidikan.

\section{Daftar Pustaka}

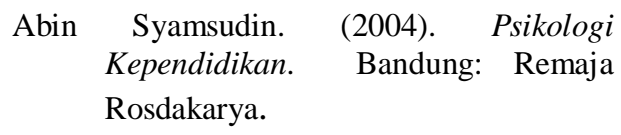


Aminah. (2012). Dasar-Dasar Pengukuran dan Statistik pada Pembelajaran Fisika. Surakarta : UNS Press

Anas Sudijono. (2007). Pengantar Statistika Pendidikan. Jakarta: PT. Raja. Grafindo.

Anita Lie. (2008). Cooperative Learning Mempraktikkan Cooperative Learning di Ruang-Ruang Kelas. Jakarta: Grasindo.

Aqib. (2011). Pendidikan Karakter Membangun Perilaku positif Anak Bangsa. Bandung: YramaWidya..

Bill Cobern. (2007). The Competing Influence of Secularism and Religion on Science Education in a Secular Society. Mallinson Institute for Science Education College of Arts \& Sciences Western Michigan University 3225 Wood Hall Kalamazo. Volume 3. 1

Budiyono. (2009). Statistika Untuk Penelitian. Surakarta: UNS Press.

BSNP. (2006). Standar Nasional Pendidikan. Jakarta: BSNP.

Chairul. (2010). Pembelajaran Fisika Berbasis Nilai Agama pada Perguruan Tinggi Agama Islam. Jurnal Penelitian Pendidikan. Vol 11 No. 2, 1.

Darmawan. (2012). Inovasi Pendidikan Pendekatan Praktik Teknologi multimedia dan Pembelajaran Online. Bandung : Remaja Rosdakarya.

Hamalik. (2003). Proses Belajar Mengajar. Jakarta: Bumi Aksara.

Maimun et al . (2011). The Use of ICT in Teaching Islamic Subjects in Brunei Darussalam. International Journal Of
Education and Information Technologies Issue (1), Volume 5, 11.

Rahman. (2007). Quranic Sciences (alih bahasa, Taufik Rahman). Bandung: Mizan.

Rusman. (2012). Belajar dan Pembelajaran Berbasis Komputer Mengembangkan Profesionalisme Abad 21. Bandung: Alfabeta.

Shihab. (1995). Membumikan Al Quran. Bandung: Mizan.

Supardi, Suhardjono.(2011). Strategi Menyusun Tindakan Kelas. Yogyakarta: Andi Offset.

Sukmadjaja Asyarie \&Rosy Yusuf. (1984). Indeks Al Quran. Bandung : Penerbit Pustaka

Suyanto. (2011). Urgensi Pendidikan Karakter.(Online)(http:// kemdiknas dikdasmen.go.id/web/pages/urgensi.ht $\mathrm{ml}$, diakses 29 November 2012)

Syaiful Muttaqin. (2008). Upaya Peningkatan Prestasi Belajar Siswa Melalui Pendekatan SainsTeknologiMasyarakat.[online].ht tp://www.syaifulmuttaqin.blogspot.co $\mathrm{m} / 2008 / 01 /$ upaya peningkatan prestasi belajar.html (diakses 1 Juni 2013)

Tim Pendidikan Karakter. (2010). Grand design pendidikan karakter. Jakarta: Kementrian Pendidikan Nasional.

Zuchdi et al. (2013) Model Pendidikan Karakter Terintegrasi dalam Pembelajaran dan Pengembangan Kultur Sekolah. Yogyakarta: MP.

Zuchdi. (2009). Pendidikan karakter grand design dan nilai-nilai target. Yogyakarta: UNY Press. 